\title{
Alternatively spliced short and long isoforms of adaptor protein intersectin 1 form complexes in mammalian cells
}

\author{
O. S. Gubar ${ }^{1,2}$, S. V. Kropyvko ${ }^{1}$, L. O. Tsyba ${ }^{1}$, S. Gasman², A. V. Rynditch ${ }^{1}$ \\ ${ }^{1}$ State Key Laboratory on Molecular and Cellular Biology \\ Institute of Molecular Biology and Genetics, NAS of Ukaine \\ 150, Akademika Zabolotnoho Str., Kyiv, Ukraine, 03680 \\ ${ }^{2}$ Institut des Neurosciences Cellulaires et Integratives (INCI) UPR 3212 \\ CNRS -Universite de Strasbourg, Centre de Neurochimie \\ 5, rue Blaise Pascal, Strasbourg, France, 67084 \\ ogubar@mail.ru
}

\begin{abstract}
Intersectin 1 (ITSN1) is an adaptor protein involved in membrane trafficking and cell signaling. Long and short isoforms of ITSN1 (ITSN1-L and ITSN1-S) are produced by alternative splicing. The aim of our study was to investigate whether ITSN1-L and ITSN1-S could interact in mammalian cells. Methods. During this study we employed immunoprecipitation and confocal microscopy. Results. We have shown that endogenous ITSN1-S coprecipitates with overexpressed ITSN1-L in PC12, 293 and 293T cells. Long and short isoforms of ITSN1 also colocalize in 293 T cells. Conclusions. ITSN1-L and ITSN1-S form complexes in mammalian cells.
\end{abstract}

Keywords: ITSN1, alternatively spliced isoforms, adaptor/scaffold proteins.

Introduction. ITSN1 is a multidomain and multifunctional adaptor protein which is involved in clathrin- and caveolin-dependent endocytosis $[1,2], \mathrm{Ca}^{2+}$-regulated exocytosis [3] and synaptic vesicles retrieval [4]. It is also implicated in cellular signaling [5-7] and neuron survival [8]. Abnormalities of ITSN1 expression are associated with the endocytic anomalies reported in Down syndrome brains and early stages of Alzheimer's disease as well as with neurodegeneration in Huntington's disease $[9,10]$. ITSN1 is also associated with glioma and neuroblastoma tumorigenesis $[11,12]$.

Two major ITSN1 isoforms are produced by alternative splicing [13]. Ubiquitously expressed ITSN1-S consists of two N-terminal EH (Eps15 homology) domains, coiled-coil region (CCR) and five SH3 (Src homology) domains. EH domains interact with NPF motifs and are highly involved in clathrin coated pits assembling [14], and SH3 domains interact with proline-rich PXXP motifs and provide protein-protein interactions

(C) Institute of Molecular Biology and Genetics, NAS of Ukraine, 2012 in many cellular processes, including membrane trafficking and signaling [15]. The long isoform of ITSN1 (ITSN1-L) is expressed predominantly in neurons and has three additional C-terminal domains: DH (dbl homology), PH (pleckstrin homology) and C2. The tandem of $\mathrm{DH}-\mathrm{PH}$ domains is a GEF (guanine nucleotide exchange factor) for the Rho-family small GTPase Cdc42 [16].

ITSN1 domain composition implies that this is an adaptor/scaffold protein. These proteins possess multiple modular interaction domains and play a crucial role in spatial and temporal organization of cellular processes. Scaffolds regulate selectivity in signaling pathways using tethering mechanism and physically assembling chosen components of signaling pathway or network [17]. It is known that some scaffold proteins dimerize or even oligomerize to perform their function $[18,19]$. As we have recently shown that ITSN1-S forms a heterodimer with its minor isoform 22a [20, 21], we presumed that probably other isoforms of ITSN1 are able to interact with each other thereby assembling protein supercomplexes. 


$\frac{P C 12}{I P} \frac{293}{I P}$

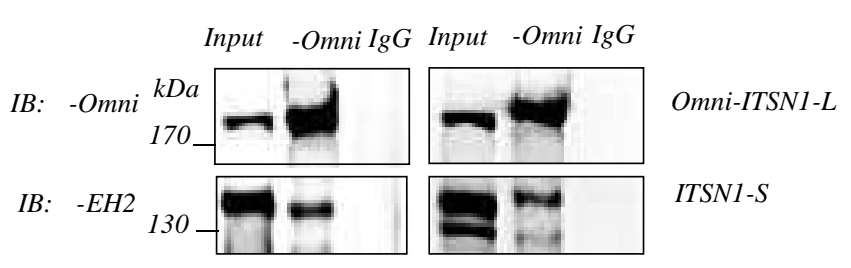

$B$

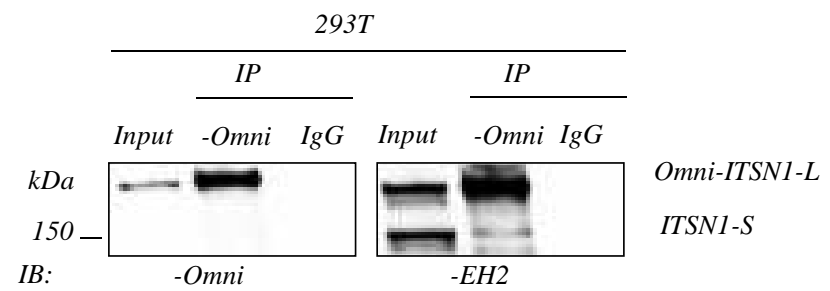

Fig. 1. ITSN1-L and ITSN1-S co-precipitate in mammalian cells. PC12 and 293 cells $(A)$ or 293 T cells $(B)$ were transfected with Omni-ITSN1$\mathrm{L}$ and subjected to immunoprecipitation $(I P)$ with anti-Omni antibody or control IgG followed by immunoblotting $(I B)$ with anti-EH2 (antiITSN1) antibody

Materials and methods. Antibodies. A monoclonal anti-Omni (D-8) antibody was from «Santa Cruz Biotechnology»(USA). Rabbit polyclonal antibodies against the EH2 domain of ITSN1 were described previously [22]. HRP-conjugated goat anti-mouse and anti-rabbit antibodies were purchased from «Invitrogen» (USA).

DNA plasmid constructs. The coding sequence of ITSN1-L was amplified from human embryonic brain cDNA and cloned into the $p c D N A 4 H i s /$ Max $C$ vector («Invitrogen»).

Plasmids encoding GFP-ITSN1-L and mCherryITSN1-S were described previously [23, 24].

Cell culture and transfection. 293 and 293T cells were obtained from the American Type Culture Collection and maintained in Dulbecco's modified Eagle's medium (DMEM) supplemented with $10 \%$ fetal calf serum («Sigma», USA), $50 \mathrm{U} / \mathrm{ml}$ penicillin and $100 \mathrm{mg} / \mathrm{ml}$ streptomycin. The cells were transiently transfected using JetPEI transfection reagent (Polyplus Transfection) according to manufacturer recommendations and further processed $24 \mathrm{~h}$ after transfection.

PC1 2 cells were maintained in DMEM supplemented with $5 \%$ fetal calf serum («Sigma»), $10 \%$ horse serum ( «Sigma»), $50 \mathrm{U} / \mathrm{ml}$ penicillin and $100 \mathrm{mg} / \mathrm{ml}$ streptomycin. The cells were transiently transfected using
Lipofectamine 2000 transfection reagent («Invitrogen») according to manufacturer recommendations and further processed $48 \mathrm{~h}$ after transfection.

Immunoprecipitation and Western blot analysis. The immunoprecipitation and Western blot were performed as described previously [25]. In brief, the cells were lysed in IP buffer (150 mM NaCl, $20 \mathrm{mM}$ Tris, $\mathrm{pH}$ 7.5, $10 \%$ glycerol, $0.5 \%$ NP40, protease inhibitors cocktail («Sigma») and centrifuged for $15 \mathrm{~min}$ at 16,000 g. Supernatant (2 $\mathrm{mg}$ of proteins) was incubated with $2 \mathrm{~g}$ an- ti-Omni antibodies and 20 1 Protein A/G Plus Ultralink Resin («Thermo Scientific», USA) for $4 \mathrm{~h}$ at $4{ }^{\circ} \mathrm{C}$. Then beads were washed four times with IP buffer without inhibitors. Immunoprecipitated complexes were eluted with Laemmli buffer, resolved by SDSPAGE and transferred to nitrocellulose membranes («Bio-Rad», USA). The membranes were blocked with $5 \%$ non-fat milk in TBS-T $(1 \times$ TBS («Euromedex», France), 0,1\% Tween 20) for $1 \mathrm{~h}$, incubated with antiOmni or anti-EH2 antibodies and washed. Detection was performed by horseradish peroxidase-conjugated goat anti-mouse or anti-rabbit antibodies.

Confocal microscopy. 293T cells were transfected with fluorescent protein constructs, fixed in $4 \%$ paraformaldehyde in PBS $24 \mathrm{~h}$ after transfection, washed two times with PBS and mounted in Mowiol medium («Sigma»). The slides were analyzed using Leica SP5 confocal microscope.

Results and discussion. In order to prove the existence of ITSN1 macromolecular complexes in cells, we have performed a co-immunoprecipitation assay in different mammalian cell lines (Fig. 1).

Omni-tagged ITSN1-L was overexpressed in rat pheochromocytoma PC12 cell line and in human 293 or $293 \mathrm{~T}$ cell lines. The immunoprecipitation was carried out with anti-Omni antibodies and further immunoblotting was performed with anti-EH2 antibodies to detect precipitated ITSN1-S. As a control of non-specific binding appropriate amount of mouse IgG was used. In all tested cell lines endogenous ITSN1-S readily co-precipitated with recombinant ITSN1-L. 293T cell line was of particular interest as it expressed endogenous ITSN1-L at relatively high level in contrast to 293 cell line (data not shown). And in addition to full-size ITSN1-L protein in 293T cells a minor band with slightly lower molecular weight is present which is presumab- 


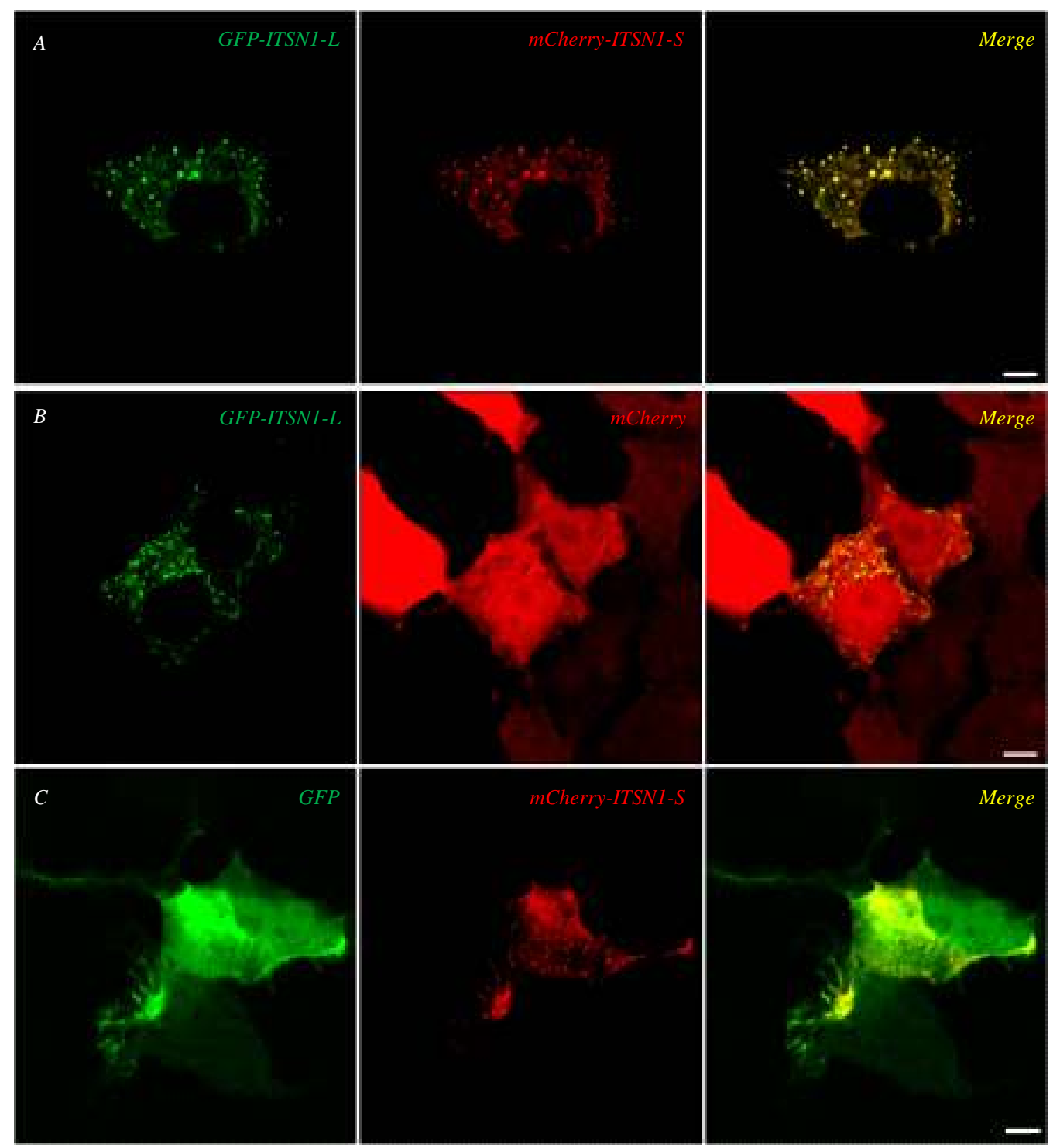

Fig. 2. Overexpressed GFPITSN1-L and mCherry-ITSN1$\mathrm{S}$ colocalize in $293 \mathrm{~T}$ cells. 293T cells were transfected with both GFP- ITSN1-L and mCherry-ITSN1-S $(A)$ or with GFP-ITSN1-L alone and empty pmCherry vector $(B)$ or with mCherry-ITSN1-S alone and empty pGFP-C1 vector $(C)$. Scale bar represents $5 \mathrm{~m}$

ly one of the possible alternatively spliced isoforms of ITSN1-L. The bands below the ITSN1-S can also refer to one of its minor isoforms, e. g. ITSN1-22a [20, 21]. And these minor isoforms also co-precipitate with overexpressed ITSN1-L suggesting that ITSN1 can form heterodimers of different isoform composition (Fig. 1, B). To explore whether ITSN1-S and ITSN1-L have similar subcellular localization, we overexpressed GFP-tagged ITSN1-L and mCherry-tagged ITSN1-S in 293T cells (Fig. 2, A).

As a control we co-expressed each of the proteins with empty vector (Fig. 2, $B, C$ ). Obtained data clearly indicate that both isoforms perfectly colocalize and have similar subcellular distribution.
So we have demonstrated that ITSN1 isoforms interact in mammalian cells, thereby forming large complexes with varying protein composition that can function in membrane trafficking as well as in cell signaling. However the molecular mechanism controlling this clusterization remains unclear.

Such ITSN1-ITSN1 interaction possibly could be mediated by CCR as it is the case for Eps15, another CCR and EH domain containing protein [26]. This supposition is also supported by the work of Wong et al. [27]. They have used a high throughput yeast two hybrid screening to define the possible partners of the ITSN scaffolds and have identified ITSN1 as a target of a prey containing its $\mathrm{EH} 2$ domain and a half of CCR 
(204-522 aa). They have further shown the existence of ITSN1 homo- and heteromeric complexes by bimolecular fluorescence complementation.

But we assume that ITSN1 SH3 domains may also contribute to this interaction as it has already been shown that some other proteins dimerize via their $\mathrm{SH} 3$ domains [28, 29]. These assumptions will be tested in our further research.

Conclusions. We have shown that ITSN1 long and short isoforms form complexes in different mammalian cell lines.

\section{О. С. Губар, С. В. Кропивко, Л. О. Циба, С. Гасман, А. В. Риндич}

Альтернативно сплайсовані коротка і довга ізоформи адапторного білка інтерсектину 1 формують комплекси у клітинах ссавців

Резюме

Інтерсектин 1 (ITSN1) - адапторний білок, залучений до мембранного транспорту та передачі клітинних сигналів. Довга і коротка ізоформи ITSN1 (ITSN1-L i ITSN1-S) утворюються в результаті альтернативного сплайсингу. Метою роботи було встановити, чи можуть ITSN1-L i ITSN1-S взаємодіяти в клітинах ссавців. Методи. Використано методи імунопреципітації та конфокальної мікроскопії. Результати. Показано, що ендогенний ITSN1S копрещипітуеться з надекспресованим ITSN1-L у клітинах PC12, 293 і 293T. Довга і коротка ізоформи ITSN1 також колокалізуються у клітинах 293T. Висновки. ITSN1-L і ITSN1-S формують комплекси в клітинах ссавців.

Ключові слова: ITSN1, альтернативно сплайсовані ізоформи, адапторні білки.

\section{О. С. Губарь, С. В. Кропивко, Л. А. Цыба, С. Гасман, А. В. Рындич}

Альтернативно сплайсированные короткая и длинная изоформы адапторного белка интерсектина 1 формируют комплексы в клетках млекопитающих

Резюме

Интерсектин 1 (ITSN1) - адапторный белок, участвующий в мембранном транспорте и передаче клеточных сигналов. Длинная и короткая изоформы ITSN1 (ITSN1-L и ITSN1-S) образуются вследствие альтернативного сплайсинга. Целью исследования было выяснить, могут ли ITSN1-L и ITSN1-S взаимодействовать в клетках млекопитающих. Методы. Использованы методы иммунопреципитации и конфокальной микроскопии. Результаты. Показано, что эндогенный ITSN1-S копреципитируется со сверхэкпрессированным ITSN1-L в клетках PC12, 293 и 293T. Длинная и короткая изоформы ITSN1 также колокализуются в клетках 293T. Выводы. ITSN1-L и ITSN1-S формируют комплексы в клетках млекопитающих.

Ключевые слова: ITSN1, альтернативно сплайсированные изоформы, адапторные белки.

\section{REFERENCES}

1. Hussain N. K., Yamabhai M., Ramjaun A. R., Guy A. M., Baranes D., O'Bryan J. P., Der C. J., Kay B. K., McPherson P. S.
Splice variants of intersectin are components of the endocytic machinery in neurons and nonneuronal cells // J. Biol. Chem.1999.-274, N 22.-P. 15671-15677.

2. Predescu S. A., Predescu D. N., Timblin B. K., Stan R. V., Malik $A$. B. Intersectin regulates fission and internalization of caveolae in endothelial cells // Mol. Biol. Cell.-2003.-14, N 12.- P. 49975010 .

3. Momboisse F., Ory S., Calco V., Malacombe M., Bader M. F., Gasman S. Calcium-regulated exocytosis in neuroendocrine cells: intersectin-1L stimulates actin polymerization and exocytosis by activating Cdc42 // Ann. NY Acad. Sci.-2009.-1152.P. 209-214.

4. Pechstein A., Bacetica J., Vahedi-Faridi A., Gromovaa K., Sundborgerb A., Tomlinb N., Krainerc G., Vorontsova O., Schafera J. G., Owed S. G., Cousine M. A., Saengera W., Shupliakov O., Haucke $V$. Regulation of synaptic vesicle recycling by complex formation between intersectin 1 and the clathrin adaptor complex AP2 // Proc. Natl Acad. Sci. USA.-2010.-107, N 9.P. 4206-4211.

5. Tong X., Hussain N. K., Adams A. G., O'Bryan J. P., McPherson $P$. S. Intersectin can regulate the Ras/MAP kinase pathway independent of its role in endocytosis // J. Biol. Chem.-2000.-275, N 38.-P. 29894-29899.

6. Adams A., Thorn J. M., Yamabhai M., Kay B. K., O'Bryan J. P. Intersectin, an adaptor protein involved in clathrin-mediated endocytosis, activates mitogenic signaling pathways // J. Biol. Chem.-2000.-275, N 35.-P. 27414-27420.

7. Novokhatska O. V., Skrypkina I. Ya., Dergai M. V., Tsyba L. O., Rynditch A. V. RTK signaling regulator SPRY2 associates with endocytic adaptor ITSN1 in vivo // Biopolym. Cell.-2012.-28, N 4.-P. 314-316.

8. Das M., Scappini E., Martin N. P., Wong K. A., Dunn S., Chen Y. J., Miller S. L., Domin J., O'Bryan J. P. Regulation of neuron survival through an intersectin-phosphoinositide 3'-kinase C2 beta-AKT pathway // Moll. Cell. Biol.-2007.-27, N 22.-P. 7906-7917.

9. Scappini E., Koh T. W., Martin N. P., O'Bryan J. P. Intersectin enhances huntingtin aggregation and neurodegeneration through activation of c-Jun-NH2-terminal kinase // Hum. Mol. Genet.2007.-16, N 15.-P. 1862-1871.

10. Keating D. J., Chen C., Pritchard M. A. Alzheimer's disease and endocytic dysfunction: clues from the Down syndrome-related proteins, DSCR1 and ITSN1 // Ageing Res. Rev.-2006.-5, N 4.P. 388-401.

11. Ma Y., Wang B., Li W., Liu X., Wang J., Ding T., Zhang J., Ying $G$., $F u L$., Gu F. Intersectin1-s is involved in migration and invasion of human glioma cells // J. Neurosci. Res.-2011.-89, N 7.P. 1079-1090.

12. Russo A., O'Bryan J. P. Intersectin 1 is required for neuroblastoma tumorigenesis // Oncogene.-2012.-doi: 10.1038/onc.2011. 643.

13. Guipponi M., Scott H. S., Chen H., Schebesta A., Rossier C., Antonarakis $S$. E. Two isoforms of a human intersectin (ITSN) protein are produced by brain-specific alternative splicing in a stop codon // Genomics.-1998.-53, N 3.-P. 369-376.

14. Morgan J. R., Prasad K., Jin S., Augustine G. J., Lafer E. M. Eps15 homology domain-NPF motif interactions regulate clathrin coat assembly during synaptic vesicle recycling // J. Biol. Chem.2003.-278, N 35.-P. 33583-33592.

15. Li S. S. Specificity and versatility of SH3 and other proline-recognition domains: structural basis and implications for cellular signal transduction // Biochem. J.-2005.-390, pt 3.-P. 641-653.

16. Hussain N. K., Jenna S., Glogauer M., Quinn C. C., Wasiak S., Guipponi M., Antonarakis S. E., Kay B. K., Stossel T. P., Lamar- 
che-Vane N., McPherson P. S. Endocytic protein intersectin-1 regulates actin assembly via Cdc42 and N-WASP // Nat. Cell. Biol.-2001.-3, N 10.-P. 927-932.

17. Good M. C., Zalatan J. G., Lim W. A. Scaffold proteins: hubs for controlling the flow of cellular information // Science.-2011.332, N 6030.-P. 680-686.

18. Maignan S., Guilloteau J. P., Fromage N., Arnoux B., Becquart $J$., Ducruix A. Crystal structure of the mammalian Grb2 adaptor // Science.-1995.-268, N 5208.-P. 291-293.

19. Elion E. A. The Ste5p scaffold // J. Cell. Sci.-2001.-114, N 22.P. 3967-3978.

20. Dergai M., Skrypkina I., Dergai O., Tsyba L., Novokhatska O., Filonenko V., Drobot L., Rynditch A. Identification and characterization of a novel mammalian isoform of the endocytic adaptor ITSN1 // Gene.-2011.-485, N 2.-P. 120-129.

21. Dergai M. V., Dergai O. V., Tsyba L. O., Novokhatska O. V., Skrypkina I. Ya., Rynditch A. V. Novel isoform of adaptor protein ITSN1 forms homodimers via its C-terminus // Biopolym. Cell.-2011.-27, N. 4.-P. 306-309.

22. Nikolaienko O., Skrypkina I., Tsyba L., Fedyshyn Y., Morderer D., Buchman V., de la Luna S., Drobot L., Rynditch A. Intersectin 1 forms a complex with adaptor protein Ruk/CIN85 in vivo independently of epidermal growth factor stimulation // Cell. Signal.-2009.-21, N 5.-P. 753-759.

23. Morderer D., Nikolaienko O., Skrypkina I., Cherkas V., Tsyba L., Belan P., Rynditch A. Endocytic adaptor protein intersectin 1 forms a complex with microtubule stabilizer STOP in neurons // Gene.-2012.-505, N 2.-P. 360-364.
24. Dergai O., Novokhatska O., Dergai M., Skrypkina I., Tsyba L., Moreau J., Rynditch A. Intersectin 1 forms complexes with SGIP1 and Reps1 in clathrin-coated pits // Biochem. Biophys. Res. Commun.-2010.-402, N 2.-P. 408-413.

25. Gubar O. S., Houy S. , Billuart P. , Kropyvko S. V., Tsyba L. O., Gasman S., Rynditch A. V. GTPase-activating protein oligophrenin 1 is a new partner of multifunctional adapter protein intersectin 1 // Biopolym. Cell.-2012.-28, N 5.-P. 357-362.

26. Cupers P., ter Haar E., Boll W., Kirchhausen T. Parallel dimers and anti-parallel tetramers formed by epidermal growth factor receptor pathway substrate clone 15 // J. Biol. Chem.-1997.-272, N 52.-P. 33430-33434.

27. Wong K. A., Wilson J., Russo A., Wang L., Okur M. N., Wang X., Martin N. P., Scappini E., Carnegie G. K., O'Bryan J. P. Intersectin (ITSN) family of scaffolds function as molecular Hubs in protein interaction networks // PLoS One.-2012.-7, N 4.e36023.

28. Kristensen O., Guenat S., Dar I., Allaman-Pillet N., Abderrahmani A., Ferdaoussi M., Roduit R., Maurer F., Beckmann J. S., Kastrup J. S., Gajhede M., Bonny C. A unique set of SH3-SH3 interactions controls IB1 homodimerization // EMBO J.-2006.25, N 4.-P. 785-797.

29. Levinson N. M., Visperas P. R., Kuriyan J. The tyrosine kinase Csk dimerizes through Its SH3 domain // PLoS One.-2009.-4, N 11.-e7683. 